\title{
Striking variations in consultation rates with general practice reveal
} family influence

\author{
Mieke Cardol*1, Liset van Dijk ${ }^{1}$, Wil JHM van den Bosch², \\ Peter Spreeuwenberg ${ }^{1}$, Dinny H de Bakker ${ }^{1}$ and Peter P Groenewegen ${ }^{1,3}$
}

\begin{abstract}
Address: ${ }^{1}$ NIVEL (Netherlands Institute for Health Services Research), Utrecht, The Netherlands, ${ }^{2}$ Radboud University, Nijmegen, The Netherlands and ${ }^{3}$ Department of Sociology and Department of Human Geography, Utrecht University, The Netherlands

Email: Mieke Cardol* - m.cardol@nivel.nl; Liset van Dijk - l.vandijk@nivel.nl; Wil JHM van den Bosch - w.vandenbosch@hag.umcn.nl; Peter Spreeuwenberg - p.spreeuwenberg@nivel.nl; Dinny H de Bakker - d.debakker@nivel.nl; Peter P Groenewegen - p.groenewegen@nivel.nl

* Corresponding author
\end{abstract}

Published: 18 January 2007

BMC Family Practice 2007, 8:4 doi:10.1 I86/147/-2296-8-4
Received: 12 June 2006

Accepted: 18 January 2007

This article is available from: http://www.biomedcentral.com/I47I-2296/8/4

(c) 2007 Cardol et al; licensee BioMed Central Ltd.

This is an Open Access article distributed under the terms of the Creative Commons Attribution License (http://creativecommons.org/licenses/by/2.0), which permits unrestricted use, distribution, and reproduction in any medium, provided the original work is properly cited.

\begin{abstract}
Background: The reasons why patients decide to consult a general practitioner vary enormously. While there may be individual reasons for this variation, the family context has a significant and unique influence upon the frequency of individuals' visits. The objective of this study was to explore which family factors can explain the differences between strikingly high, and correspondingly low, family consultation rates in families with children aged up to 21 .
\end{abstract}

Methods: Data were used from the second Dutch national survey of general practice. This survey extracted from the medical records of 96 practices in the Netherlands, information on all consultations with patients during 200I. We defined, through multilevel analysis, two groups of families. These had respectively, predominantly high, and low, contact frequencies due to a significant family influence upon the frequency of the individual's first contacts. Binomial logistic regression analyses were used to analyse which of the family factors, related to shared circumstances and socialisation conditions, can explain the differences in consultation rates between the two groups of families.

Results: In almost $3 \%$ of all families, individual consultation rates decrease significantly due to family influence. In $11 \%$ of the families, individual consultation rates significantly increase due to family influence. While taking into account the health status of family members, family factors can explain family consultation rates. These factors include circumstances such as their economic status and number of children, as well as socialisation conditions such as specific health knowledge and family beliefs. The chance of significant low frequencies of contact due to family influences increases significantly with factors such as, paid employment of parents in the health care sector, low expectations of general practitioners' care for minor ailments and a western cultural background.

Conclusion: Family circumstances can easily be identified and will add to the understanding of the health complaints of the individual patient in the consulting room. Family circumstances related to health risks often cannot be changed but they can illuminate the reasons for a visit, and mould strategies for prevention, treatment or recovery. Health beliefs, on the other hand, may be influenced by providing specific knowledge. 


\section{Background}

People's decisions to consult a general practitioner vary enormously [1-7]. Next to individual differences that influence consultation rates, the social context of the family has an important and unique influence on individual consultation behaviour. To a certain extent family members resemble each other in their consultation behaviour, even across generations [8]. The association between contact frequencies of mothers and children, especially girls, is well-known $[9,10]$. Previous studies showed that fathers' frequencies of contact are also associated with those of mothers, and of children [5,11]. Similarity in consultation rates is especially true for families that present with minor ailments such as headache or abdominal pain [11]. So why do members of one family resemble each other in their consultation behaviour? By this behaviour we mean both, in consultation frequencies, as well as health ailments for which a general practitioner is consulted. Explanations must be sought in socialisation and shared family circumstances [12]. Socialisation refers to the internalisation of family beliefs and attitudes related to health and health behaviour. What can be considered illness, and when a visit to a general practitioner is appropriate, are learned within families [8]. Here knowledge is probably influential. A mother's educational level has been shown to be a strong predictor of the frequency of children's new consultations [13]. Shared circumstances refer to a collective social, physical and financial context in which opportunities for health, or threats to health occur. Shared circumstances such as the kind of insurance [14] or family size [15] can explain similarities in consultation rates with general practice among individual family members. With regard to the larger families, time constraints and experience may be of importance. For example, in larger families, parents may have less time to monitor closely the health of all members [15]. On the other hand, earlier research showed that mothers more often consult general practice with their first born than with subsequent children [14]. This may indicate that parents of larger families are more experienced in health care matters, resulting in fewer consultations for all members. Thus, the family context may influence consultation behaviour in such a manner that, for example, from a family viewpoint, the decision not to visit the general practitioner is a logical one. However, from a different viewpoint, a visit may seem appropriate.

Differences between families can help to explain differences in individual consultation rates. If socialisation processes and family circumstances can explain consultation patterns, this would mean that family factors, other than an individual's illness, are part of the decision to consult the general practitioner. Family attitudes towards illness may prevent people from consulting a doctor in time, resulting in unnecessary difficulties for patients or more costs for the health care system. For general practitioners it is interesting to know which family factors influence individual frequencies of contact. This may help both to understand the reasons underlying individual consultations, and to choose adequate strategies for treatment or communication. The question posed in this study is: To what extent can the family context explain differences between both strikingly high, and low, consultation rates among families with children aged up to 21 ?

\section{Methods \\ Data}

Data were used from the second Dutch national survey of general practice [16]. This survey extracted information on all consultations with patients during 2001, from the medical records of 96 practices in the Netherlands $(2 \%$ of the total number of Dutch practices). These practices were representative of the Netherlands patient population with respect to sex, age, type of health care insurance, and level of urbanisation. The general practitioners in the practices were representative of the Dutch population of general practitioners in most aspects. Only general practitioners working solo were relatively under-represented (31\% versus $43 \%$ ).

Background information about family members' sociodemographic characteristics was collected by means of a one-page questionnaire with 14 items in four languages sent to all people listed with the 96 practices (response: $77 \% ; n=294999$ ) [16]. This questionnaire could also be filled in on the internet. A random sample of the Dutchspeaking population of the participating practices took part in an extended health interview at the patients' homes (response 65\%; $n=12$ 699). Respondents of the health interviews were more often female as compared to the Dutch population (54\% versus $51 \%$ ) and more often had a western cultural background (96\% versus 91\%). Educational level, socio-economic status and selfreported health status were comparable to the Dutch population.

The interview included questions about health complaints, use of health services, attitudes and beliefs. Only one member from each family was interviewed; responses were attributed to all members of that family. In children aged under 12, the interview was conducted with a parent. The internal validity of the one-page questionnaire and the health interview were good [16].

\section{Dependant variables: realisation of three groups of families}

Families were defined as having at least one parent living together with at least one child and being listed in the same practice. Almost all non-institutionalised Dutch citizens are listed in a general practice. Family members are 
usually listed in the same practice. General practice therefore provides adequate information for studying consultation behaviour in families. For this study we selected families with one or more children aged $<=21$ years. The minimum age of children was set at two years because children below this age also attend baby or child health clinics. Families with children below the age of two or above the age of 21 were not excluded. Only the children in the specific age categories were excluded. This resulted in a study population of 42397 families (Table 1).

Dependent on the size of the practice, about 152 to 1360 families attended the same practice (median 334). Earlier research into this study population showed that the family accounted for $22 \%$ of the variance in the frequency of individuals' first contacts [5].

In the present study we used a multilevel poisson regression model with three levels, individual, family and practice, to define three groups of families based on their family effects [17]. This family effect cannot be measured directly, therefore we extracted it from the frequency of contacts of individual family members. Contact frequency is defined as the number of face-to-face contacts counted for an individual in a year. Only the first contacts in any one period of sickness were chosen because the patients'

Table I: Study data: sources, variables, selections and incomplete information

\begin{tabular}{|c|c|c|c|}
\hline Source & Study population & \multicolumn{2}{|c|}{ Selection } \\
\hline $\begin{array}{l}\text { One year registration of all face- } \\
\text { to-face contacts of individuals in } \\
\text { electronic medical records }\end{array}$ & I60 926 individuals; 42397 families & \multicolumn{2}{|c|}{$\begin{array}{l}\text { Families with children } 2-2 \text { I yrs (siblings of } 0-2 \text { yrs or }>21 \text { yrs within } \\
\text { families were excluded) }\end{array}$} \\
\hline $\begin{array}{l}\text { One-page questionnaire sent at } \\
\text { the patient's home }\end{array}$ & I60926 individuals; 42397 families & \multicolumn{2}{|c|}{$\begin{array}{l}\text { Families with children } 2-21 \text { yrs (siblings of } 0-2 \text { yrs or }>21 \text { yrs within } \\
\text { families were excluded) }\end{array}$} \\
\hline $\begin{array}{l}\text { Extended health interview at the } \\
\text { patient's home }\end{array}$ & 5313 individuals aggregated to families & \multicolumn{2}{|c|}{ One member of families with children 2-2I yrs } \\
\hline Variable view & Source & Categorisation & $\begin{array}{l}\text { Incomplete information } \\
\text { on family level }\end{array}$ \\
\hline Generation & One-page questionnaire & Parent Child & none \\
\hline Age & One-page questionnaire & $\begin{array}{l}\text { Excluded: families with siblings }>21 \\
\text { yrs (\%) }\end{array}$ & none \\
\hline Sex & One-page questionnaire & Male Female & none \\
\hline \multirow[t]{3}{*}{ Family health status } & registration in medical record & $\begin{array}{l}\text { Consultations for minor ailments: } \\
\text { yes/no }\end{array}$ & none \\
\hline & & $\begin{array}{l}\text { Consultations for chronic illness: } \\
\text { yes/no }\end{array}$ & none \\
\hline & One-page questionnaire & $\begin{array}{l}\text { Self-reported health status ranging } \\
\text { from I (very good) to } 5 \text { (very bad) }\end{array}$ & 10366 \\
\hline \multicolumn{4}{|c|}{ Indicators for shared circumstances } \\
\hline Insurance type & One-page questionnaire & Social insurance Private insurance & 10176 \\
\hline Educational level parents & One-page questionnaire & $\begin{array}{l}\text { Low/moderate: primary and } \\
\text { secondary education High: post } \\
\text { secondary and tertiary education }\end{array}$ & 12162 \\
\hline Number of children & One-page questionnaire & $\begin{array}{l}\text { Minimum: one parent and one } \\
\text { sibling }\end{array}$ & None \\
\hline Mother's employment & One-page questionnaire & Paid work yes/no & 3626 \\
\hline \multicolumn{4}{|c|}{ Indicators for socialisation } \\
\hline Cultural background parents & One-page questionnaire & $\begin{array}{l}\text { Both western Heterogeneous Both } \\
\text { non-western }\end{array}$ & 10301 \\
\hline $\begin{array}{l}\text { Parents' employment in the health } \\
\text { care sector }\end{array}$ & One-page questionnaire & $\begin{array}{l}\text { All levels of employment in the } \\
\text { health care sector: yes/no }\end{array}$ & None \\
\hline $\begin{array}{l}\text { Attitude towards management of } \\
\text { minor ailments }\end{array}$ & Health interview & $\begin{array}{c}\text { Sumscore on Nijmegen Expectation } \\
\text { Questionnaire, range 12-60 }\end{array}$ & 2899 \\
\hline Trust in general practitioners' care & Health interview & $\begin{array}{l}\text { One-item question asking for a } \\
\text { mark; range } 1-10\end{array}$ & 2608 \\
\hline Self-care activities & Health interview & $\begin{array}{l}\text { Conducting self-care in case of } \\
\text { minor ailments: yes/no }\end{array}$ & 106 \\
\hline
\end{tabular}


initiatives are most clear in these contacts. The fixed part of the multilevel model shows the overall mean frequency of contact. Individual consultation rates were predicted on the basis of a parent or child's age and sex, and controlled for clustering of individuals in families, and families in practices. The random part of the model shows the variance on the three levels: individual variance within families; variance between families; and variance between practices. The latter not only captures the influence of general practitioners, but also the geographical contexts of families, because almost all patients live in close proximity to the practice. For this study we used the estimates on the family level, that is family deviation of the overall mean frequency of contact, to define the family effect. This way the family effect consists solely of the unique contribution of families upon the frequency of contact of the individual, corrected for all the other components in the model. The families were then divided into three groups, based on this family effect. The first group of families are called 'lowering-effect families' - families in which members on average have lower contact frequencies than expected based on their age, generation (being a child or parent) and sex. The family effect in this group is statistically significant and negative, which means that family influences cause their frequencies of contact to decrease. The second group of families is composed of those with a significant positive family effect. We call them 'raising-effect families'. In these families, members on average have higher frequencies of contact than one would expect given their age, generation and sex. In these two groups of families the family effect makes a significant difference. The third group consists of average families in which the family effect is associated with both higher and lower frequencies of contact than can be expected on the basis of the individual's characteristics. This third group will only be used as a comparison with the attributes of the families at the extremes (Tables 2 and $3)$.

\section{Independent variables \\ Health status}

Health status is the most important predictor for consultation rates of individuals $[1,8]$. Health status was evaluated both by individual patients own reports of their health and by the health complaints for which they have consulted their general practitioner. From the medical records we constructed two variables. Firstly, whether family members had consulted general practice for minor ailments such as headache or abdominal pain [18]. And secondly, whether they consulted general practice about a chronic disease [19]. Furthermore, based on the one-tem question of the Short-Form-36 (SF-36; [20]) a mean family score of self-reported health status, ranging from 1 to 5; (very) good to (very) bad, was calculated (Table 1).

\section{Shared circumstances}

Shared circumstances were defined as: The type of insurance; the educational level of the parents; the employ-

Table 2: Characteristics of the study population

\begin{tabular}{|c|c|c|c|c|c|c|}
\hline \multirow[b]{2}{*}{ Individual level } & \multicolumn{2}{|c|}{$\begin{array}{l}\text { Lowering-effect } \\
\text { families }\end{array}$} & \multicolumn{2}{|c|}{ Average families } & \multicolumn{2}{|c|}{ Raising-effect families } \\
\hline & $\begin{array}{l}\text { Parents } \\
(n=2508)\end{array}$ & $\begin{array}{l}\text { Siblings } \\
(n=3316)\end{array}$ & $\begin{array}{c}\text { Parents } \\
(\mathrm{n}=66863)\end{array}$ & $\begin{array}{c}\text { Siblings } \\
(n=7|I| 4)\end{array}$ & $\begin{array}{c}\text { Parents } \\
(n=8356)\end{array}$ & $\begin{array}{l}\text { Siblings } \\
(n=8769)\end{array}$ \\
\hline Mean age (sd; range) & $\begin{array}{c}40.5 \\
(6.9 ; 21-65)\end{array}$ & $\begin{array}{c}10.5 \\
(5.2 ; 2-21)\end{array}$ & $\begin{array}{c}40.4 \\
(7.0 ; 21-65)\end{array}$ & $\begin{array}{c}10.5 \\
(5.3 ; 2-21)\end{array}$ & $\begin{array}{c}39.4 \\
(7.1 ; 21-65)\end{array}$ & $\begin{array}{c}10.3 \\
(5.5 ; 2-2 \mid)\end{array}$ \\
\hline Mean frequency of contact (max) & $\begin{array}{l}0.1 \\
(3)\end{array}$ & $\begin{array}{l}0.1 \\
(3)\end{array}$ & $\begin{array}{l}1.2 \\
(9)\end{array}$ & $0.9(10)$ & $\begin{array}{l}3.5 \\
(33)\end{array}$ & $\begin{array}{l}2.8 \\
(17)\end{array}$ \\
\hline$\%$ individuals with zero contacts in registration year & 88.2 & 91.4 & 40.2 & 48.3 & 8.2 & 10.7 \\
\hline \multirow[t]{2}{*}{$\%$ respondents reporting moderate to bad health status ${ }^{1}$} & 9.1 & 2.7 & 12.7 & 3.8 & 21.4 & 6.7 \\
\hline & \multicolumn{2}{|c|}{$\begin{array}{l}\text { Lowering-effect } \\
\text { families }\end{array}$} & \multicolumn{2}{|c|}{ Average families } & \multicolumn{2}{|c|}{ Raising-effect families } \\
\hline Family level & \multicolumn{2}{|c|}{ 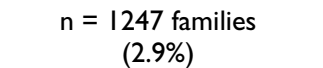 } & \multicolumn{2}{|c|}{$\begin{array}{c}\mathrm{n}=36641 \text { families } \\
(86.4 \%)\end{array}$} & \multicolumn{2}{|c|}{$\begin{array}{c}\mathrm{n}= \\
\quad 4509 \text { families } \\
(10.6 \%)\end{array}$} \\
\hline Mean number of years listed in current practice & \multicolumn{2}{|c|}{12.8} & \multicolumn{2}{|c|}{13.5} & \multicolumn{2}{|c|}{13.2} \\
\hline$\%$ one parent families & \multicolumn{2}{|c|}{$7.9 *$} & \multicolumn{2}{|c|}{20.9} & \multicolumn{2}{|c|}{19.1} \\
\hline Mean number of siblings & \multicolumn{2}{|c|}{$3^{*}$} & \multicolumn{2}{|c|}{2} & \multicolumn{2}{|c|}{2} \\
\hline$\%$ privately insured & \multicolumn{2}{|c|}{$58.4 *$} & \multicolumn{2}{|c|}{46.7} & \multicolumn{2}{|c|}{34} \\
\hline$\%$ one/both parents non-western cultural background & \multicolumn{2}{|c|}{$8.7^{*}$} & \multicolumn{2}{|c|}{9.7} & \multicolumn{2}{|c|}{16.1} \\
\hline$\%$ families mothers high educational level & \multicolumn{2}{|c|}{$28^{*}$} & \multicolumn{2}{|c|}{22.5} & \multicolumn{2}{|c|}{13} \\
\hline$\%$ families mother paid employment & \multicolumn{2}{|c|}{$32^{*}$} & \multicolumn{2}{|c|}{43.4} & \multicolumn{2}{|c|}{37.1} \\
\hline$\%$ families mothers working in health care sector & \multicolumn{2}{|c|}{$12.7^{*}$} & \multicolumn{2}{|c|}{10.1} & \multicolumn{2}{|c|}{7.3} \\
\hline$\%$ families fathers working in health care sector & \multicolumn{2}{|c|}{$5.9 *$} & \multicolumn{2}{|c|}{2.2} & $\mathrm{I}$. & \\
\hline
\end{tabular}

1 respondents $>=12$ yrs

$*$ differences between lowering-effect and raising-effect families are significant at $p<0.05$ 
Table 3: Family health status and attitudes' towards minor ailments and health care services, by family group

\begin{tabular}{|c|c|c|c|}
\hline & $\begin{array}{l}\text { Lowering-effect families } \\
\qquad(\mathrm{n}=1247)\end{array}$ & $\begin{array}{l}\text { Average families } \\
\quad(n=36641)\end{array}$ & $\begin{array}{l}\text { Raising-effect families } \\
\quad(n=509)\end{array}$ \\
\hline $\begin{array}{l}\% \text { of families with illness episode(s) of minor ailments for } \\
\text { which the GP was consulted }\end{array}$ & $19.9 *$ & 67.2 & 96.0 \\
\hline \multirow{2}{*}{$\begin{array}{l}\% \text { of families with illness episode(s) of chronic disease for } \\
\text { which the GP was consulted }\end{array}$} & $19.9 *$ & 56.0 & 82.2 \\
\hline & $\begin{array}{l}\text { Lowering-effect families } \\
\qquad(\mathrm{n}=135)\end{array}$ & $\begin{array}{l}\text { Average families } \\
\quad(n=4604)\end{array}$ & $\begin{array}{l}\text { Raising-effect families } \\
\qquad(n=574)\end{array}$ \\
\hline$\%$ respondents using self-care strategies for minor ailments & $77.8^{*}$ & 81.8 & 86.1 \\
\hline Mean sum score Nijmegen Expectation Questionnaire ${ }^{2}$ & $45.7 *$ & 43.5 & 42.5 \\
\hline $\begin{array}{l}\% \text { respondents reporting unsatisfactory marks for trust in } \\
\text { health care }\end{array}$ & 23.3 & 23.0 & 21.9 \\
\hline $\begin{array}{l}\text { \% respondents reporting unsatisfactory marks for trust in } \\
\text { general practitioner care }\end{array}$ & 11.7 & 15.3 & 19.9 \\
\hline
\end{tabular}

1 information from the health care interviews

2 higher scores denote fewer beliefs about the benefits of general practitioner's care for minor health ailments

$*$ differences between families with higher and lower individual contact frequencies are significant at $\mathrm{p}<0.05$

ment of the mother; and the number of children (Table 1 ). The type of insurance was used as a proxy for social economic status. At the time of this study the insurance in the Netherlands was related to patients' income. About two-thirds of the population had obligatory social insurance, whereas people with a higher income had private insurance. In addition, the educational level of the parents was used as an indicator for social status and income. Since the influence of the mother is still dominant, as far as consultation patterns of children are concerned [14], the mother's employment was used as an indicator for time constraints to attend general practice. The number of children in a family refers to time constraints [15] or experience [14].

\section{Socialisation}

The study design was cross-sectional, which makes it impossible to focus on the process of socialisation. Rather, we evaluated socialisation conditions including: the health knowledge of the parents; family health beliefs, such as expectations of general practice care in case of minor ailments; trust in health care; and performance of self-care activities (Table 1). Parents employment in the health care sector was evaluated as an indicator for specific knowledge and networks with knowledge, which is known to affect attitudes and beliefs related to health and health care use [21]. People with a non-western background have a different life-style and different health beliefs as compared to people from a western background, for example regarding eating habits, smoking and the use medication $[22,23]$. Cultural background was therefore used as a proxy for health beliefs, and divided into 'western', people from industrialised countries, and 'non-western', people from non-industrialised countries.
Attitudes towards the management of minor ailments were evaluated with the validated Nijmegen Expectation Questionnaire as part of the health interview [24]. In this questionnaire respondents' attitudes are ascertained in 12 statements concerning the possible benefits of consulting a general practitioner as compared to self-care. A higher score denotes less belief in the benefits of consulting general practice for common ailments, which means that a person will probably not attend general practice for those complaints. Trust in health care was measured using marks on a scale of one to ten, in which one to five denote unsatisfactory marks. Furthermore, in the health interview, respondents reported whether they opt for self-care when they do not feel well. This gives an impression about their awareness of symptoms and feelings of control over their own health.

\section{Analyses}

Descriptive analyses were used to report on the health status of individual family members, shared socio-economic circumstances, and attitudes towards health and health care for the above mentioned three groups of families. Binomial logistic regression analysis was used to analyse to what extent factors related to socialisation and family circumstances can predict the probability of being a lowering-effect family as compared to a raising-effect family (reference group). The analysis was done twice, once based on the entire population (Table 4), and once based on the respondents of the health interviews (Table 5). The second analysis includes more indicators for socialisation, but the power of the analysis is lower due to a smaller sample size. Therefore, in the analyses presented in Table 5 , we omitted all insignificant variables of the final model in Table 4. Both regression analyses were done in three 
Table 4: Probability of predicting lowering-effect families as compared to raising-effect families; binomial logistic regression analysis in three steps $(n=3$ I 56 families)

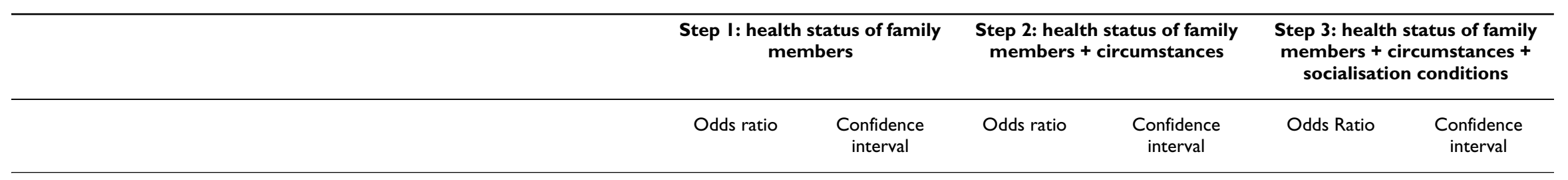

Health status

Chronic disease in the family (no $=$ ref)

$\begin{array}{llllll}0.12^{* *} & 0.09-0.14 & 0.10^{* *} & 0.08-0.14 & 0.10^{* *} & 0.08-0.13 \\ 0.35 * * & 0.28-0.45 & 0.44 * * & 0.34-0.56 & 0.47^{* *} & 0.37-0.61\end{array}$

Family score self-reported health (higher score $=$ more members reported bad health)

$0.28-0.45$

$0.44^{*}$

$0.47^{* *}$

$0.37-0.61$

Family circumstances

Private insurance $($ social $=$ reference $)$

Educational level mother $($ low $=$ ref $)$

Educational level father $($ low $=$ ref)

Number of children

Paid employment mother $($ no $=$ ref $)$

$\begin{array}{llll}2.36 * * & 1.85-3.01 & 2.18^{* *} & 1.71-2.79 \\ 1.28 & 0.79-2.08 & 0.88 & 0.54-1.45 \\ 1.87^{*} & 1.08-3.23 & 1.60 & 0.92-2.78 \\ 2.25 * * & 1.99-2.53 & 2.27 * * & 2.01-2.56 \\ 1.02 & 0.80-1.30 & 0.97 & 0.76-1.23\end{array}$

Indicators for socialisation

Father or mother paid employment in health care sector (not $=$ ref)

Both parents western cultural background (one or both non-western $=$ ref) 
Table 5: Probability of predicting lowering-effect families as compared to raising-effect families; binomial logistic regression analysis in three steps $(\mathrm{n}=\mathbf{2 5 7}$ respondents of the health interview aggregated to families)

\begin{tabular}{|c|c|c|c|c|c|c|}
\hline & \multicolumn{2}{|c|}{$\begin{array}{l}\text { Step I: health status of } \\
\text { family members }\end{array}$} & \multicolumn{2}{|c|}{$\begin{array}{l}\text { Step 2: health status of family } \\
\text { members + circumstances }\end{array}$} & \multicolumn{2}{|c|}{$\begin{array}{l}\text { Step 3: health status of family members }+ \\
\text { circumstances }+ \text { socialisation conditions }\end{array}$} \\
\hline & Odds ratio & Confidence interval & Odds ratio & Confidence interval & Odds Ratio & Confidence interval \\
\hline \multicolumn{7}{|l|}{ Health status } \\
\hline Chronic disease in the family (no = ref) & $0.13^{* *}$ & $0.06-0.30$ & $0.13 * *$ & $0.04-0.27$ & $0.14 * *$ & $0.05-0.38$ \\
\hline $\begin{array}{l}\text { Family score self-reported health (higher score }=\text { more members reported bad } \\
\text { health) }\end{array}$ & $0.19 * *$ & $0.08-0.46$ & $0.30 *$ & $0.12-0.87$ & 0.38 & $0.14-1.03$ \\
\hline \multicolumn{7}{|l|}{ Family circumstances } \\
\hline Private insurance (social = reference) & & & $2.63 *$ & $1.07-6.42$ & $3.01 *$ & $1.11-8.13$ \\
\hline Number of children & & & $2.40 * *$ & $1.59-3.64$ & $2.47^{* *}$ & $1.57-3.88$ \\
\hline \multicolumn{7}{|l|}{ Indicators for socialisation } \\
\hline Father or mother paid employment in health care sector (not $=$ ref) & & & & & 2.40 & $0.82-7.01$ \\
\hline Both parents western cultural background (one or both non-western $=$ ref) & & & & & 0.37 & $0.07-2.11$ \\
\hline Sum score Nijmegen expectation Questionnairel & & & & & $1.14^{*}$ & $1.04-1.24$ \\
\hline Self-care in minor ailments & & & & & 0.54 & $0.19-1.54$ \\
\hline \multirow[t]{2}{*}{ Not much trust in GPs (much $=$ ref) } & & & & & 0.23 & $0.04-1.22$ \\
\hline & \multicolumn{2}{|r|}{0.30} & \multicolumn{2}{|r|}{0.43} & \multicolumn{2}{|r|}{0.51} \\
\hline Percentage correct & \multicolumn{2}{|r|}{87.9} & \multicolumn{2}{|r|}{87.9} & \multicolumn{2}{|r|}{89.5} \\
\hline
\end{tabular}

2

I a higher score denotes lower expectations

* significant at the level of $\mathrm{p}<0.05$

ए $* *$ significant at the level of $p<0.01$ 
steps to differentiate between the influence of health status, family circumstances and socialisation conditions. Correlations between independent variables did not exceed 0.4 .

\section{Results}

In almost 3\% of all families, the family effect on individual consultation rates was significantly negative (lowering-effect families), in $11 \%$ of the families the family effect was significantly positive: these are the raising-effect families. Based on the multilevel analyses, the average effect of lowering-effect families on the frequencies of individuals first contacts is -0.5 contacts per year, per individual (95\% CI: -0.9 to -0.3 ;). In these families, the contact frequency per year for each family member is 0.5 lower than can be expected on the basis of age and sex. For the raising-effect families this figure is +1.6 per year, per individual (95\% CI: +0.5 to +5.3$)$.

As expected, in raising-effect families more members rate their health as bad (Table 2). Furthermore, lowering-effect families on average have more children, a private insurance and the parents more often have a higher educational level. Parents in these families more often work in the health care sector. The health interviews show that respondents from lowering-effect families have fewer expectations of general practitioners' care in cases of minor ailments than respondents from raising-effect families (Table 3). The amount of trust in general practitioner care does not differ significantly between the family groups.

In the logistic regression analysis we analysed to what extent health status, shared family circumstances and socialisation conditions can explain differences in consultation behaviour between lowering-effect and raisingeffect families (Table 4). In step one we included family health status variables. The chance of low frequencies of contact due to a family effect is reduced by an episode of chronic illness suffered by one of the family members, but also, though to a lesser extent, by family members reporting themselves as having a worse health status. In step two, variables referring to shared circumstances were entered into the analysis. It shows that a higher socio-economic status, as indicated by private insurance, and to a lesser extent the fathers' educational level, both increase the probability of a lowering-effect family. The effect of more siblings in the family is as strong as the effect of being privately insured. Whether the mother has paid employment does not make a significant difference.

In step three, socialisation conditions are added to the model. Paid employment of one of the parents in the health care sector, and both parents having a western cultural background, significantly increase the chance of low frequencies of contact due to a family effect. When adding the indicators for socialisation, the effect of the fathers' educational level is no longer significant. In Table 5 other socialisation conditions, based on the health interview, have been added to the regression model. By doing this, employment in the health care sector and cultural background no longer explain differences between loweringeffect and raising-effect families. Expectations of doctor's care in case of minor ailments do explain part of the differences between lowering-effect and raising-effect families. In the final model, in both analyses, the percentage of correct classification is almost $90 \%$.

\section{Discussion}

This research focuses on the family influence upon an individual's consultation behaviour. The results indicate that striking variations in family consultation rates can be explained, especially by the family health status, but also by family circumstances such as economic status and number of children, as well as socialisation factors such as health knowledge and family beliefs. This study is unique in that the effect of the family has been translated into higher or lower individual contact frequencies than could be expected on the basis of an individual's characteristics. For example, per individual, per year, members of lowering-effect families have 0.5 fewer first contacts than could be expected, based upon their individual characteristics. This may not seem much, but it is substantial in view of the individual mean frequency of first contacts: 1 contact for each member per year.

It must be noted that in this study we evaluated the family effect on frequencies of contact in general. Related to specific diagnoses the family effect on frequencies of contact may show other relationships.

\section{Results in view of the literature and general practice}

The family health status explains most variance in consultation behaviour between the families. This corresponds with the existing literature on individual consultation behaviour [1]. However, the health status of individual family members alone cannot sufficiently explain why in some families, members consult more often than in other families [25]. Family health is thought to be more than the sum of its parts; it connotes the functioning of the family as a primary agent in the promotion of health and well-being [8].

In addition to family health status, another consideration for general practitioners is whether a patient belongs to a larger family, since this decreases the odds for high consultation rates due to family influence. As stated in the introduction, a lack of time [15] or the parents greater experience [14] in health care matters are suggested as other possible explanations. The results of this study point 
towards experience as an explanation, since the paid employment of mothers, as an indicator for time constraints, did not make a significant difference. Yet another explanation is that in families in which the parents or a first child are not healthy, fewer children are born. As such, the explanation would refer to a selection of more healthy individuals in larger families.

Indeed, knowledge and the family's health beliefs, influence people's use of health services alongside other considerations such as the family health status and shared circumstances [26]. The family is the first context where this is learned, which makes it all the more important for general practitioners to be informed about the patients' social context. Parents paid employment in health care partly explains why families consult less. In those families members have fewer expectations of general practitioners' care for minor ailments and they probably have more specific knowledge and useful networks [21]. Apparently, specific knowledge has more impact than a high educational level. We cannot draw conclusions on the basis of this study about the appropriateness of the contacts with general practice. However this could mean that in families in which the family influence causes consultation rates to increase, it would help to provide more specific knowledge. For example to inform family members about the background and treatment of minor ailments and about when one needs to be concerned about one's health. The results also show that families with more specific knowledge are no more likely to opt for more self-care. Apparently, self-care does not substitute for practice visits. Other studies show that more self-care is associated with more contacts with the practice [21]. Maybe the specific knowledge of health care workers results in a more stoic attitude towards health ailments: they have seen people with poorer health conditions.

The family context is a factor general practitioners can identify in the consultation room that will add to their understanding of the health complaints of the individual patient. To do so, easy and feasible questions have been developed for use in consultations to enable the general practitioner to be informed about the family context of individual patients $[2,3,27]$.

\section{Limitations of the study}

The cross-sectional design of the study made it difficult to evaluate socialisation processes. Instead, we made use of indicators to evaluate socialisation conditions and socioeconomic family circumstances. Our indicators were based, as much as possible, on existing knowledge, but they may still have caused bias. Also, the questions asked in the health interview were not directed at family functioning and family relationships, known to be of impor- tance for outcomes related to health and consultation patterns [3].

Furthermore, the relatively small sample that completed the health interviews restricted the possibilities and power of the second regression analysis. We had to eliminate the non-significant variables from the analyses to keep a stable model. To limit the risk of bias this may have caused, we analysed the omitted variables in separate logistic analyses, controlled for the family health status. By doing this, only the educational level of the father was significant ( $p=0.01)$. However, accounting for the educational level of the father in the final analysis did not produce different results. But this may also be caused by the issue of missing data. Information about the type of insurance, the educational level of the parents and the cultural background of the parents was missing in about $20 \%$ of the families. Such incomplete information about the educational level of the parents and cultural background, occurred significantly more often in the families with strikingly low consultation rates.

\section{Conclusion}

This study shows that general practitioners need to take the social context of patients into account. Information about their patients' social contexts helps general practitioners to add or delete probabilities that may point towards correct diagnoses and treatment.

Next to the family health status, shared circumstances and socialisation play an important role. Such factors as a high income, larger family size, specific health knowledge, health beliefs, and expectations of care, explain part of the differences in contact frequencies between families with low and families with high consultation rates, due to a family effect. Specific knowledge and/or networks in the health care sector seem more influential than the educational level of the parents. Socio-economic circumstances often cannot be changed but may shed a different light on prevention, treatment or recovery. In conclusion, for general practitioners, it seems fruitful to stay alert to factors beyond individual illness and to make the extra benefits of such a contextual approach more visible. In the Netherlands, they are the only health practitioners that can take advantage of the fact that they often see members of the same family in their consulting room.

\section{Competing interests}

The author(s) declare that they have no competing interests.

\section{Authors' contributions}

MC, LvD, WvdB, DdeB and PG were involved in the study design. Primary data-analysis was conducted by PS and $\mathrm{MC}$, with the other authors contributing. MC drafted the 
paper, which was revised by all co-authors. All authors read and approved the final manuscript.

\section{Acknowledgements}

The authors like to thank the Netherlands Organisation for Health

Research and Development (ZonMw) for funding this project.

\section{References}

I. Andersen TF, Newman JF: Societal and Individual Determinants of Medical Health Care Utilization in the United States. Milbank Mem Fund Q 1973, 81:95-I 23.

2. Campbell TL, Culpepper L: Family medicine. In Oxford textbook of primary medical care Volume I. Edited by: Jones R, Britten N, Culpepper L, Gass D, Grol R, Mant D, Silagy C. Oxford: Oxford University Press; 2004:299-309.

3. Huygen FJA: Family medicine; the medical life history of families Nijmegen: Dekker \& Van de Vegt; 1978.

4. Hippisley-Cox J, Coupland C, Pringle M, Crown N, Hammersley V: Married Couples' Risk of Same Disease: Cross Sectional Study. BMJ 2002, 325:636-640.

5. Cardol M, Groenewegen PP, De Bakker DH, Spreeuwenberg P, Van Dijk L, Van den Bosch WJHM: Shared Help-Seeking Behaviour Within Families; a Restrospective Cohort-Study. BMJ 2005, 330:882-884.

6. Campbell NC, Iversen L, Farmer J, Guest C, MacDonald JA: Qualitative Study in Rural and Urban Areas on Whether - and Howto Consult During Routine and Out of Hours. BMC Fam Pract; 2006, 7(26):

7. Rosenstock I: Why People Use Health Services. Milbank Mem Fund $Q$ 1966, 44:94-127.

8. Litman TL: The Family As a Basic Unit in Health and Medical Care: a Social-Behavioral Overview. Soc Sci Med 1974, 8:495-519.

9. Wyke S, Hewison J, Russell IT: Respiratory Illness in Children: What Makes Parents Decide to Consult? Br J Gen Pract 1990, 40:226-229.

10. Mechanic D: The Influence of Mothers on Their Children's Health Attitudes and Behavior. Pediatrics 1964, 33:444-453.

II. Cardol M, Van den Bosch WJHM, Spreeuwenberg P, Groenewegen PP, Van Dijk L, De Bakker DH: All in the Family: Headaches and Abdominal Pain As Indicator for Consultation Patterns in Families. Ann Fam Med 2006, 4(6):506-II.

12. Cardol M, Groenewegen PP, Spreeuwenberg P, Van Dijk L, Van den Bosch WJHM, De Bakker DH: Why Does It Run in Families? Explaining Help-Seeking Behaviour by Shared Circumstances, Socialisation and Selection. Soc Sci Med 2006, 63:920-932.

13. Campion P, Gabriel J: Illness Behaviour in Mothers With Young Children. Soc Sci Med 1985, 20:325-330.

14. Van den Bosch WJHM, Huijgen FJA, Van de Hoogen HJM, Van Weel C: Morbidity in Early Childhood: Family Patterns in Relation to Sex, Birth Order, and Social Class. Fam Med 1993, 25: $126-130$.

15. Wilcox-Gok VL: Sibling Data and the Family Background Influence on Child Health. Med Care 1983, 21:630-638.

16. Schellevis FG, Westert GP: The design of the second Dutch National Survey of General Practice. In Morbidity, performance and quality in primary care Edited by: Westert GP, Jabaaij L, Schellevis FG. Oxford: Radcliff Publishing; 2006:10-18.

17. Snijders TAB, Bosker RJ: Multilevel analysis; an introduction to basic and advanced multilevel modelling London: Sage Publications; 1999.

18. IJzermans J, Donker G, Vasterman P: The impact of disasters: long term effects on health. Public Health in Europe: 10 years European Public Health Association Edited by: Kirch W. Berlin/Heidelberg: Springer; 2004:317-34I.

19. Van den Berg J, Van der Wulp CG: Rapport van de werkgroep revisie POLS-Gezondheidsenquete 1999 Voorburg/Heerlen: CBS; 2003.

20. McHorney CA, Ware JEJ, Lu JF, Sherbourne CD: The MOS 36-Item Short-Form Health Survey (SF-36): III. Tests of Data Quality, Scaling Assumptions, and Reliability Across Diverse Patient Groups. Med Care 1994, 32:40-66.

21. Furer JW: Protoprofessionalisering; een empirisch onderzoek naar de validiteit van protoprofessionalisering en naar haar verbanden met gezond(heids)gedrag, ziektegedrag en gezondheidstoestand Thesis University of Nijmegen; $200 \mathrm{I}$.

22. Cardol M, Schellevis FG, Spreeuwenberg P, Van de Lisdonk EH: Changes in Patients' Attitudes Towards the Management of Minor Ailments. Br J Gen Pract 2005, 55:5I 6-52I.

23. Reijneveld SA: Reported Health, Lifestyles, and Use of Health Care of First Generation Immigrants in the Netherlands: Do Socio-Economic Factors Explain Their Adverse Position? JECH 1998, 52:298-304.

24. Van de Lisdonk EH: Ervaren en aangeboden morbiditeit in de huisartspraktijk [Morbidity in general practice] Thesis University of Nijmegen; 1985.

25. Dowrick C: Why Do the O'Sheas Consult So Often? An Exploration of Complex Family IIIness Behaviour. Soc Sci Med 1992, 34:49I-497.

26. Kirscht JP: The Health Belief Model and Illness Behavior. Health Educ Monographs 1974, 2:387-408.

27. Launer J, Lindsey C: Training for Systematic General Practice: a New Approach From the Tavistock Clinic. Br J Gen Pract 1997, 47:453-456.

\section{Pre-publication history}

The pre-publication history for this paper can be accessed here:

http://www.biomedcentral.com/1471-2296/8/4/prepub
Publish with Biomed Central and every scientist can read your work free of charge

"BioMed Central will be the most significant development for disseminating the results of biomedical research in our lifetime. "

Sir Paul Nurse, Cancer Research UK

Your research papers will be:

- available free of charge to the entire biomedical community

- peer reviewed and published immediately upon acceptance

- cited in PubMed and archived on PubMed Central

- yours - you keep the copyright

Submit your manuscript here:

http://www.biomedcentral.com/info/publishing_adv.asp
BiolMedcentral 